\title{
Tectonic Significance of Topographic Lineament Analysis Using Artificial Illumination: Offshore Southwestern Taiwan
}

\author{
Jinder Chow \\ Professor, Institute of Applied Geophysics, National Taiwan Ocean University, Keelung, Taiwan, R.O.C., \\ jdchow@ms24.hinet.net \\ Tzun-Der Lai \\ Graduate student, Institute of Applied Geophysics, National Taiwan Ocean University, Keelung, Taiwan, R.O.C. \\ Char-Shine Liu \\ Professor, Institute of Oceanography, National Taiwan University, Taipei, Taiwan, R.O.C. \\ Robert Sun \\ Professor, Department of Earth Sciences, National Chenkung University, Tainan, Taiwan, R.O.C.
}

Follow this and additional works at: https://jmstt.ntou.edu.tw/journal

Part of the Earth Sciences Commons

\section{Recommended Citation}

Chow, Jinder; Lai, Tzun-Der; Liu, Char-Shine; and Sun, Robert (2004) "Tectonic Significance of Topographic Lineament Analysis Using Artificial Illumination: Offshore Southwestern Taiwan," Journal of Marine Science and Technology: Vol. 12: Iss. 2, Article 5.

DOI: $10.51400 / 2709-6998.2226$

Available at: https://jmstt.ntou.edu.tw/journal/vol12/iss2/5

This Research Article is brought to you for free and open access by Journal of Marine Science and Technology. It has been accepted for inclusion in Journal of Marine Science and Technology by an authorized editor of Journal of Marine Science and Technology. 


\section{Tectonic Significance of Topographic Lineament Analysis Using Artificial Illumination: Offshore Southwestern Taiwan}

\section{Acknowledgements}

Thanks are due to Dr. Benoit Deffontaines of Universite Pierre et Marie Curie (France) for careful reading and offering valuable suggestion. This research was supported by the National Science Council of Taiwan Government. We express our appreciation to the officers and crew of the R/V Ocean Researcher I for providing support for seismic survey. 


\title{
TECTONIC SIGNIFICANCE OF TOPOGRAPHIC LINEAMENT ANALYSIS USING ARTIFICIAL ILLUMINATION: OFFSHORE SOUTHWESTERN TAIWAN
}

\author{
Jinder Chow*, Tzun-Der Lai**, Char-Shine Liu***, and Robert Sun****
}

Key words: topographic lineament, seismic section, strike-slip fault.

\begin{abstract}
A digital topographic relief map, shaded by means of artificial illumination, has been compiled for southwestern Taiwan for a lineament analysis of the area. We discover a pronounced fanning toward the southwest in the lineaments. Six major offsets of lineaments have been identified, with the following trends: $\mathrm{N} 60^{\circ} \mathrm{E}, \mathrm{N} 60^{\circ} \mathrm{E}, \mathrm{N} 65^{\circ} \mathrm{E}$, $\mathrm{N} 85^{\circ} \mathrm{E}$, and $\mathrm{N} 40^{\circ} \mathrm{W}$. The trends of the offsets can all be correlated with faults predicted by experimental models of right-lateral strikeslip deformation. This paper presents a detailed submarine topographic lineament analysis in southwestern Taiwan and provides additional evidence of Lu's model for the vast offshore area.
\end{abstract}

\section{INTRODUCTION}

The island of Taiwan occupies a zone of convergence between the Philippine Sea plate and the Eurasian plate and has been recognized as a model site for oblique arc-continent collision [2, 4, 6, 10, 14, 18, 25, 29]. In the studied southwestern Taiwan area (Fig. 1), Lu [20] has noted the role of the rigid Peikang Basement High in determining the structural configuration of the collision zone (Fig. 2): on the northeastern side of the high, a left-lateral shear zone exists, while on the southeastern side of the high, a right-lateral shear zone exists. South of the rigid basement block is a zone of escape structures which may have been formed as material was forced out of the path of the impinging block of rigid

Paper Submitted 03/17/04, Accepted 05/03/04. Author for Correspondence: Jinder Chow. E-mail: jdchow@ms24.hinet.net.

*Professor, Institute of Applied Geophysics, National Taiwan Ocean University, Keelung, Taiwan, R.O.C.

**Graduate student, Institute of Applied Geophysics, National Taiwan Ocean University, Keelung, Taiwan, R.O.C.

***Professor, Institute of Oceanography, National Taiwan University, Taipei, Taiwan, R.O.C.

****Professor, Department of Earth Sciences, National Chenkung University, Tainan, Taiwan, R.O.C. crustal basement. Lu's [20] escape model provides a useful framework to understand the neotectonic features on the island of Taiwan, but Lu's [20] paper lacks supporting don't have any data in the offshore area to test his theory. The offshore data of this paper provide additional evidence of the vast area.

Some of the structural features of the offshore area of southern Taiwan, representing the incipient stage of collision, have been identified in previous studies. Liu et al. [19] concluded that thrust faulting is the major structural feature in the accretionary wedge in this area. However, a study by Chow et al. [8] unveiled the presence of shear structures (including flower structures and strike-slip faulting) off the southwestern coast of Taiwan, north of $22^{\circ} \mathrm{N}$. Strike-slip faulting in the area off the southern coast of Taiwan has also been described by Fuh et al. [12], based on a detailed study of seismic reflection profiles. Fuh et al. [12], however, did not identify any of these structures as the offshore extensions

Many previous studies [5, 9, 10, 15, 16, 19, 22, 28] have described the relationship between faulting and the well-known mud diapirs and mud volcanoes in the study area. Chang [5] concluded that the faulting in the area exerts some influence on the distribution of the mud diapirs, but he did not attempt to explain the relationship. Huang et al. [16] also broadly attributed the en-echelon pattern of the mud diapir ridges in the study area to regional tectonic stress patterns. Liu et al. [19] proposed that growth of the offshore mud diapirs was triggered by thrusting, but they did not consider the possible influence of strike-slip deformation. One of the goals of the present study is to determine the extent of strike-slip deformation in the study area.

The ability to identify geologic structures, such as faults and folds, through lineament analysis using digital topographic data has been demonstrated by a recent study of the Canadian Arctic [21]. Deffontaines et al. [11] pointed out that most of the onshore lineaments on 
the island of Taiwan can be linked to specific geologic features, such as the Longitudinal Valley Fault Zone, the Lishan Fault, and the fault zones along the Western Foothills. Song et al. [27] also used the lineament patterns off the coast of northern Taiwan to study the origin of the Chilung Valley. A shaded topographic map made from digital topographic data has been previously published for the area off the southern coast of Taiwan [12], but our study is the first one to carry out a detailed lineament analysis on this type of map.

In this study, an analysis of surface lineament patterns using digital topographic data from the area off the southwest coast of Taiwan has been supplemented with interpretations from seismic reflection profiles for the purpose of defining the neotectonic features of the offshore area. In order to accentuate linear features, the digital topographic data were artificially illuminated from different angles according to the method of Siegal and Short [26]. As a result of this study, probable offshore extensions of the onshore escape structures have been identified in the area south of $23^{\circ} \mathrm{N}$.

\section{DATA AND METHODOLOGY}

The study area covers both onshore and offshore areas of southwestern Taiwan, and extends from $119^{\circ} 20^{\prime} \mathrm{E}$ to $121^{\circ}$ and from $22^{\circ} \mathrm{N}$ to $23^{\circ} 15^{\prime} \mathrm{N}$ (Fig. 1 ).

\section{Digital Topographic Data}

Topographic data for onshore areas and bathymetric data for offshore areas were first combined into a single data bank, and were then interpolated into a grid framework. A minimum curvature surface method was used to create a Mercator-projection map; a tension parameter of 0.75 was chosen in order to minimize distortion.

Topographic lineaments were enhanced by filter-

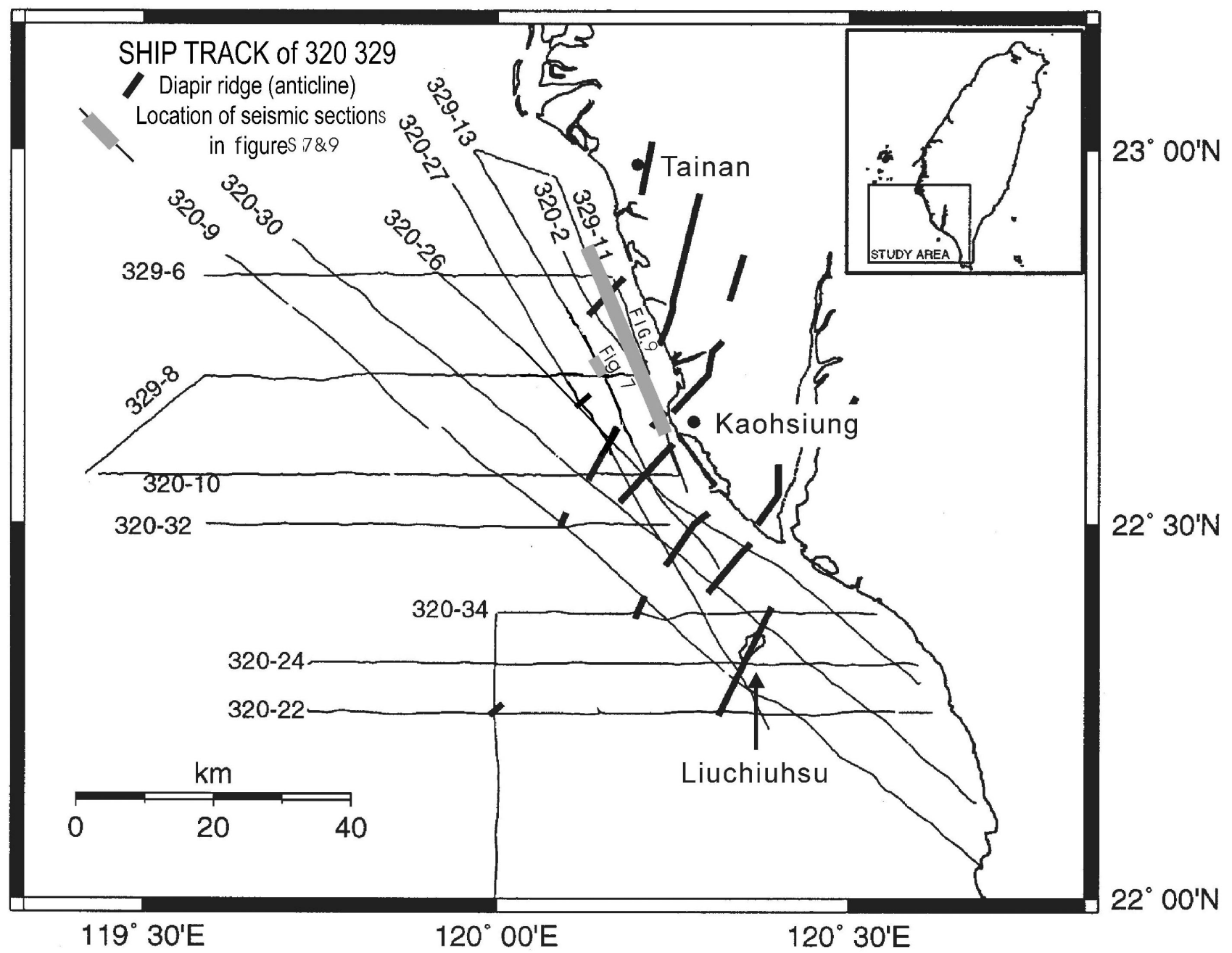

Fig. 1. The location of seismic sections and en-echelon diapir ridges which trending $\mathrm{N}^{\circ} 5^{\circ} \mathrm{E}$ (compiled from Huang et al., 1995 ) in the study area. 
ing out both low- and high-frequency noise from the data bank, using GMT software (version 3) in a SUN workstation. By trial and error, it was determined that lineaments were most prominent using data with wavelengths in the range of $4-10 \mathrm{~km}$. The filtered topographic relief data were then illuminated artificially from different angles in order to discover the optimum angle for enhancement of the structural discontinuities in the study area. On a shaded topographic relief map, lineaments perpendicular to the illumination angle are usually the most prominent ones [21,26].

\section{Seismic Data}

The seismic reflection data used in this study are taken from profiles obtained by Cruises 320 and 329 of the R/V Ocean Researcher I (Fig. 1). The two-channel, single-fold profiles were processed using SIOSEIS software. Preliminary analyses of these sections have been presented in a previous study by Chow et al. [8], which documented the existence of certain features characteristic of strike-slip deformation, namely, flower structures. Since the length limitation of this paper, we only display two seismic sections instead of showing all the seismic sections we studied.

\section{LINEAMENT ANALYSIS}

Figure 3 is constructed from the land topographic data in combination with marine bathymetric data. Figure 3 shows the major geomorphic provinces of the study area. These maps depict the terrain clearly in its true complexity. Figure 4 is an enlarged land topographic shaded relief map of Figure 3. In Figures 3 and 4 , the illumination comes from $\mathrm{S} 60^{\circ} \mathrm{E}$ and $\mathrm{N} 60^{\circ} \mathrm{W}$ respectively, and features perpendicular to this direction are emphasized. In this type of representation (Figs. 3 and 4), both light and dark tones indicate areas of high relief (slopes dipping toward the illumination are lightened, while slopes dipping away from the illumination are darkened); intermediate tones indicate areas of gentle terrain.

\section{Description of Lineaments}

In Figure 3, lineaments on the continental slope (Fig. 3, E1 E4) can be divided into four zones: west of $119^{\circ} 53^{\prime} \mathrm{E}$ (E1), the lineaments trend from NW-SW to N$\mathrm{S}$; between $119^{\circ} 53^{\prime} \mathrm{E}$ and Kaoping Canyon (F), there is a middle zone (E2) characterized by NNW-SSE lineaments overprinted with lineaments running NNE-SSW; and in the east, there are two zones (E3 and E4) which are characterized by NW-SE lineaments. Differences in the major trends of the lineaments in these four zones may be related to the change in the dip of the continental slope. However, the overprinted NNE-SSW lineaments in the middle zone (E2) and the NW-SE lineaments in the eastern zones (E3 and E4) are extensions of, or are parallel to, the trends of lineaments on the coastal land, and thus appear to be structurally controlled.

Figure 4 shows that some known faults coincide with the lineaments. For example, the Chaochou Fault (A) coincides with the terminations of lineaments and serves as the boundary between the Central Range ( $\mathrm{C}$ in Fig. 3) and the Pingtung Floodplain (B in Fig. 3). On the other hand, some faults offset the lineaments, for example, the Jenwu Fault (L) coincides with the offset of the lineaments (Fig. 4).

To facilitate interpretation, some areas containing prominent lineaments were enlarged (Figs. 5 and 6) and observed from different illumination angles. Yu and Chang (2002) described the main course of the Penghu Submarine Canyon of the southwestern Taiwan extends in a nearly north-south direction. Therefore, some of the lineaments in the study area are of erosional origin. Although the highlighted lineaments in Figs. 5 and 6 are possibly tectonic or/and erosional features, we can derive strike-slip movement from the offset of the lineaments. This means either these lineaments are of tectonic origin or erosional origin, if the lineaments have offsets, strike-slip faulting occurred. The existence of strike-slip fault can be proved by the flower structure on the seismic section in the study area (Fig. 7). From the lineament offsets and terminations that were observed when the continental slope area was illuminated from $\mathrm{N} 25^{\circ} \mathrm{E}$, the existence of four fault sets was inferred with trends as follows: $\mathrm{N} 60^{\circ} \mathrm{E}$, $\mathrm{N} 60^{\circ} \mathrm{E}, \mathrm{N} 65^{\circ} \mathrm{E}$, and $\mathrm{N} 85^{\circ} \mathrm{E}$ (Fig. 5). With illumination from $\mathrm{S} 60^{\circ} \mathrm{E}$, another fault was inferred trending $\mathrm{N} 40^{\circ} \mathrm{W}$ in the area off the coast of Kaoshiung (Fig. 6). The significance of these faults will be discussed below.

\section{Fan-shaped Distribution of Lineaments and the Escape Model}

Some onshore lineaments can also be seen to extend offshore, such as the N-S lineament that follows the Chaochou Fault and the NE-SW lineaments that extend from the Pingtung Floodplain (Fig. 8). The extension of prominent lineaments in the study area shows a fanning from the Chaochou Fault toward the southwest, a pattern which becomes more prominent in the offshore area (Fig. 8). This fan-shaped pattern of lineaments supports the escape model proposed by $\mathrm{Lu}$ [20]: according to Lu's model, this kind of fan-shaped pattern would be expected to result from the regional stress patterns around the basement high. 


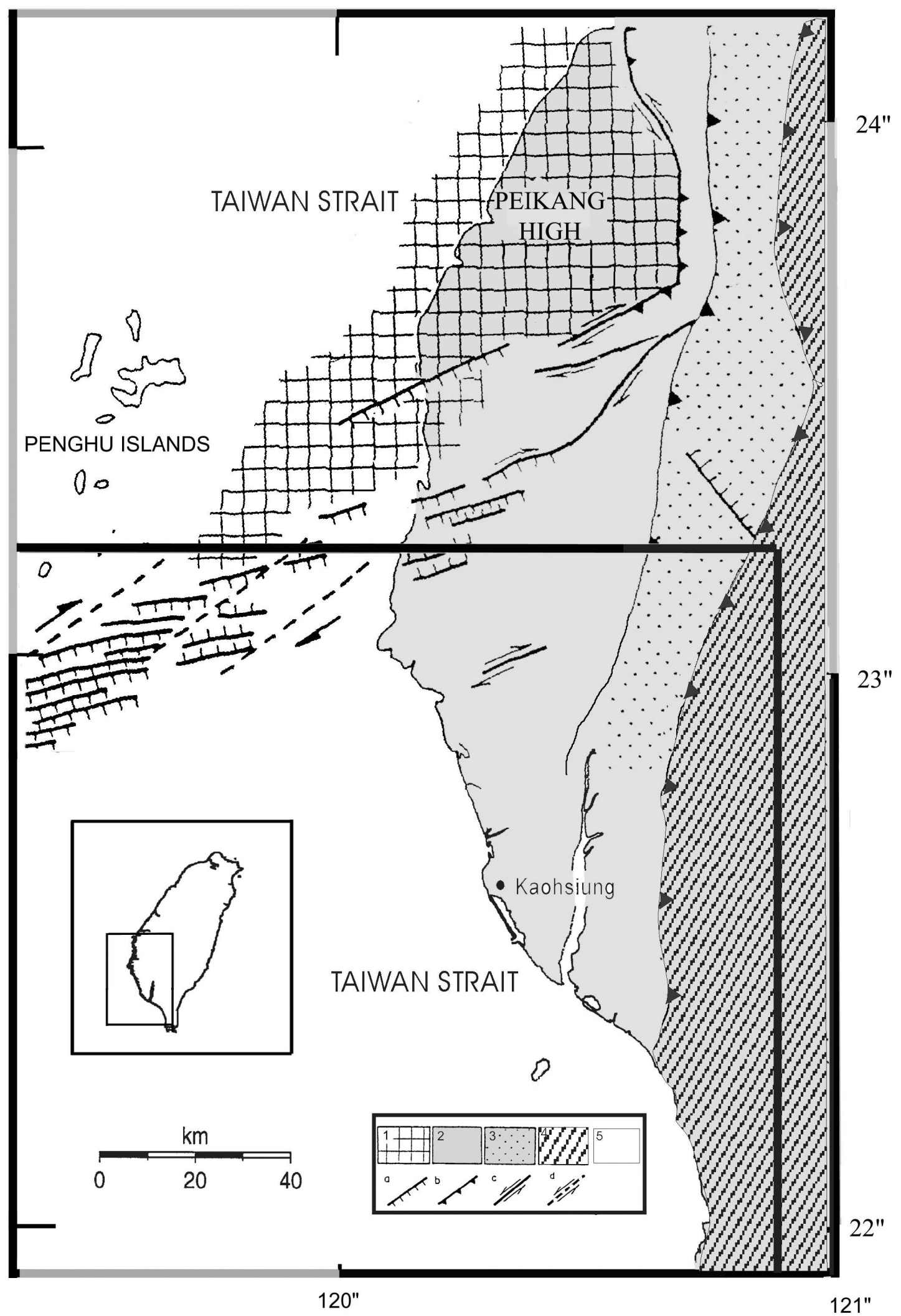

Fig. 2. Map showing the present-day indentation and escape tectonics of western Taiwan (after Biq, 1990; Lu, 1994). Key: (1) The presumed indenter, the Peikang Basement High. (2) The Coastal Plain. (3) The Western Foothill area. (4) Central Mountain. (5) The Taiwan Strait. (a) Normal fault, (b) thrust fault, (c) strike-slip fault, (d) uncertain strike-slip fault. The box in the lower half shows the location of the study area. 


\section{Mud Diapirs in the Lineament Fanning Zone}

Some of the offshore seismic profiles cross the fan-shaped pattern of lineaments (See Figures 1 and 8 for the location of seismic lines). On seismic profile 329-11 (Fig. 9), two mud diapirs that are typical of those within the lineament fanning zone (Fig. 8) can be clearly distinguished from surrounding strata. The mud diapirs were possibly triggered and formed by thrust faults majorly and possibly with minor strike-slip component. The reason is that the surrounding faults of the fan head such as Chaochou Fault and Jenwu Fault are thrust faults with strike-slip component related to the mechanism of fan formation. (Figs. 4 and 8). Strata were domed upward over the diapirs, while the strata between the diapirs were warped or faulted downward in an intervening graben or an egg-carton shaped depression (G). As explained in the next section, we propose that folding within the escape tectonics regime was possibly one of the driving mechanisms for the formation of the mud diapers in this region.

\section{The Strike-slip Deformation Model}

Many of the structural features of the study area are explicable in terms of right-lateral strike-slip deformation. This can be supported by comparing the trends of the structural features in the area with the main features developed during experimental strike-slip deformation. In a well-known study, Wilcox et al. [30] identified these features according to their position on a strain ellipse (Fig. 10A). Strain ellipse plots of the trends of the dominant structural features in an area can be helpful in determining the tectonic setting in which they formed. Using this method, Rohr and Dietrich [24] were able to convincingly explain the azimuthal distribution of faults in the offshore area of western Canada within a framework of right-lateral strike-slip deformation. For the purpose of this study, we have also plotted the mentioned azimuths of the faults, such as $\mathrm{N} 85^{\circ} \mathrm{E}$, that were inferred in Section 3.1 on a strain ellipse (Fig. 10B); on the same strain ellipse (Fig. 10B), we also show the dominant axial trend of the diapir

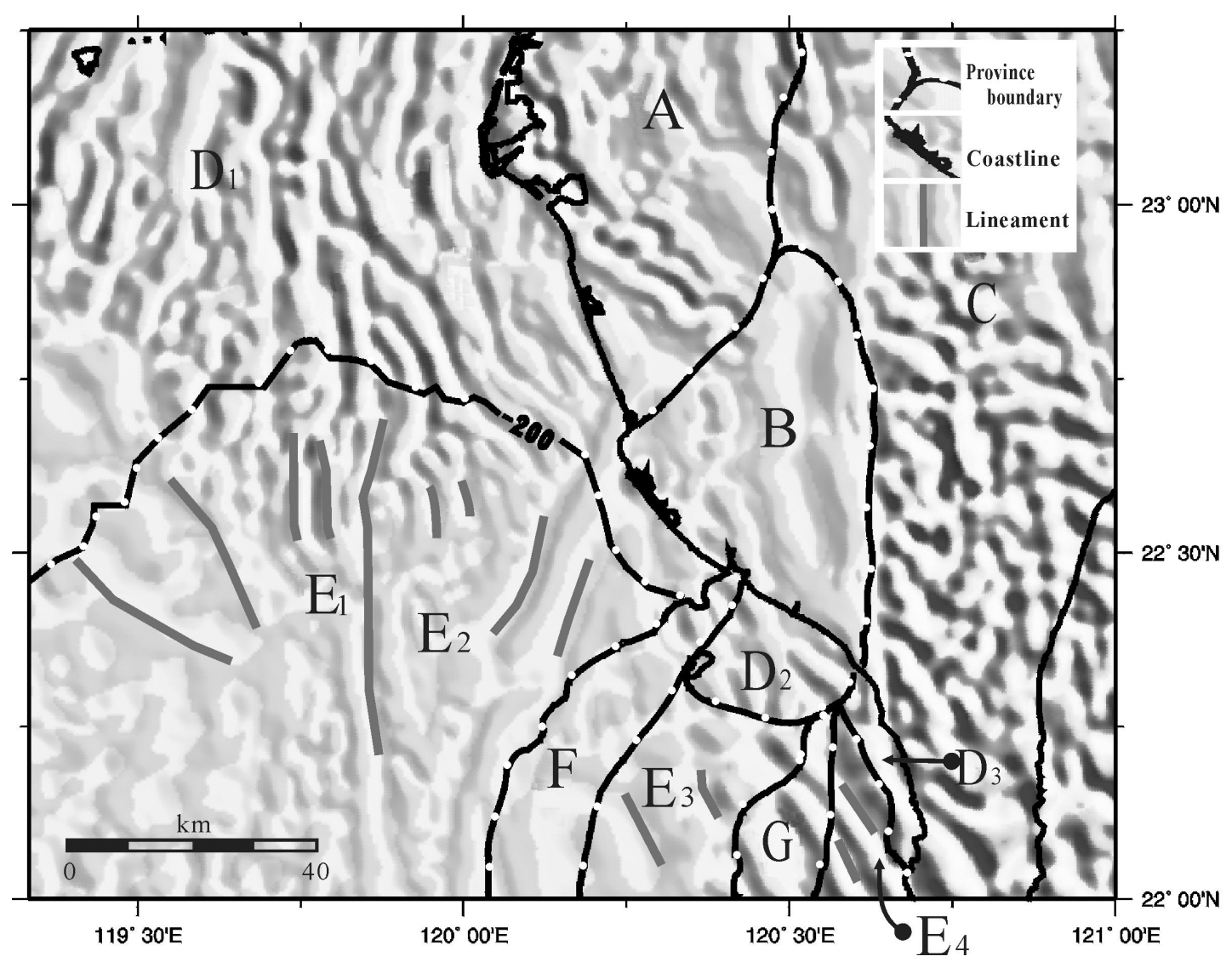

Fig. 3. A new shaded relief map of southwestern Taiwan (illumination source from $\mathrm{S60}{ }^{\circ} \mathrm{E}$ ), showing the following geomorphic provinces: (A) the Chianan Plain, (B) the Pingtung Floodplain, (C) the Central Range, (D) the continental shelf D1-D3, (E) the gullied continental slope E1-E4, (F) Kaoping Canyon, and (G) Fangliao Canyon. The black lines with white dots are province boundaries. The location of this map is shown in the lower half box of Fig. 1. 
ridges, $\mathrm{N} 35^{\circ} \mathrm{E}$, in Figure 1. If we assume that the direction of maximum compressive stress is equivalent to the direction of plate convergence between the Phil-
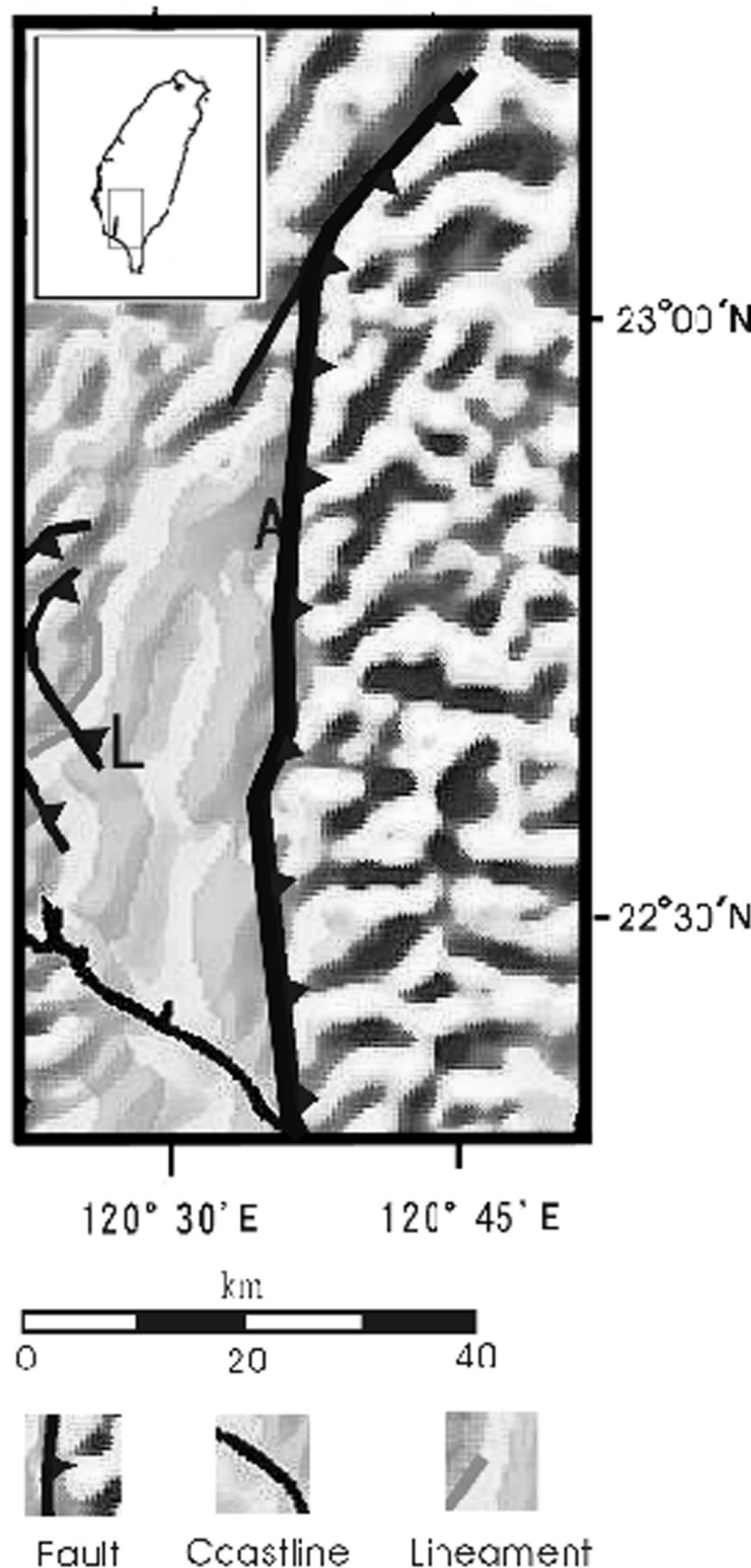

Fig. 4. Enlarged shaded topographic map with illumination source from $\mathrm{N}^{\circ} 0^{\circ} \mathrm{W}$. Box of upper-left corner indicates the location of the topographic map. Traces of onshore thrust faults with strike-slip component are shown in heavier black lines: (A) Chaochou Fault, (L) Jenwu Fault. Location of Chaochou Fault (A) coincides with the terminations of lineaments. Short gray lines indicate lineaments offset by Jenwu Fault. The irregular black line is the coastline. ippine Sea plate and the Eurasian plate, the resulting strain ellipse for right-lateral strike-slip faulting accounts very well for the structures observed in the study area. The match of these features is good, considering that heterogeneities in nature often cause significant departures from laboratory results [13]. The $\mathrm{N} 85^{\circ} \mathrm{E}$ (Fig. 10B) fault derived from lineament offset in previous section corresponds with the direction of main displacement, $Y$, in the strain ellipse (Fig. 10A). The two faults trending of $\mathrm{N} 60^{\circ} \mathrm{E}$ to $\mathrm{N} 65^{\circ} \mathrm{E}$ (Fig. 10B) correlate well with the $P$ shear, while the $\mathrm{N} 40^{\circ} \mathrm{W}$ (Fig. 10B) fault may represent the $R^{\prime}$ shear (Fig. 10A). In addition, the direction of the $\mathrm{R}$ shear (Fig. 10A) in the strain ellipse is similar to the trends of the strike-slip faulting, i.e. $\mathrm{N} 80^{\circ} \mathrm{W}$, observed in the flower structures of Chow et al. [8].

The domed strata of the diapirs and the downward warping of the intervening graben (Fig. 9) are similar to the strata deformations that are typically seen in enechelon folding [30]. The trend of the offshore mud

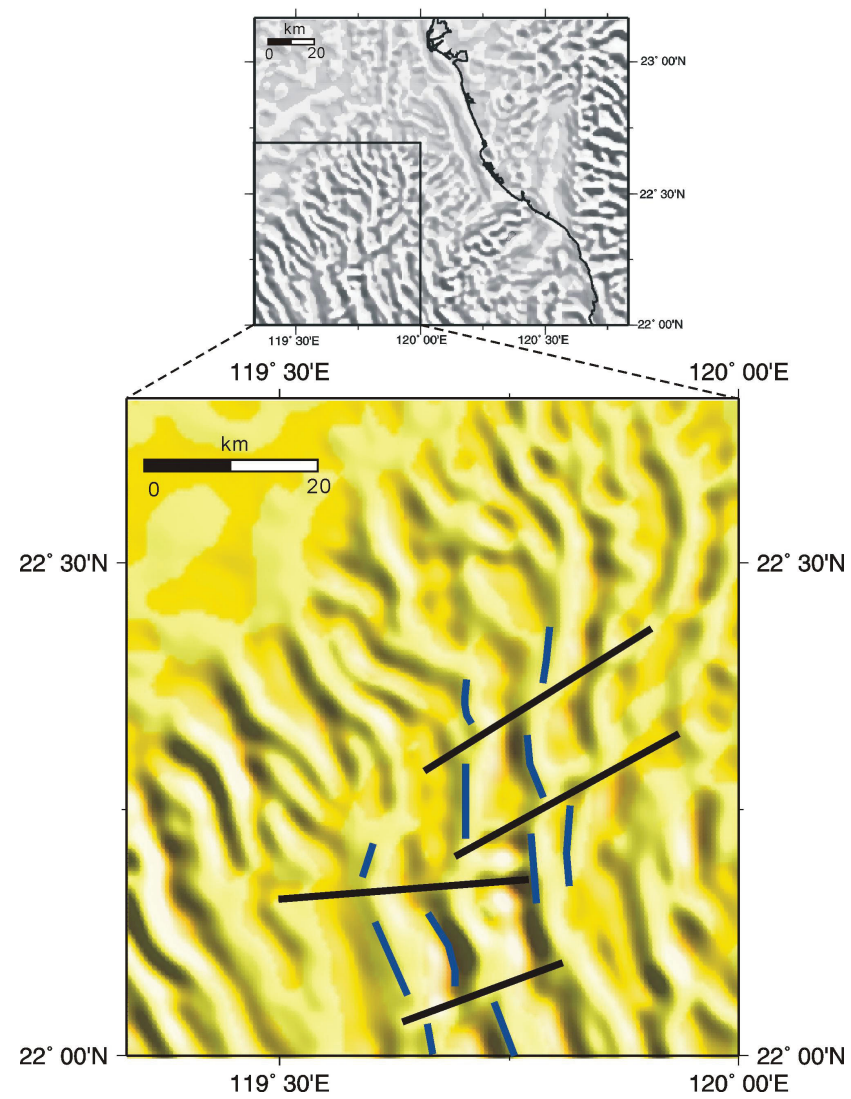

Fig. 5. Enlarged area (the lower figure) illuminated from $\mathbf{N} 25^{\circ} \mathbf{E}$ showing how lineament (gray lines) offsets and terminations were used to infer the existence of four faults (black lines) with the following trends: $\mathrm{N}^{\circ} 0^{\circ} \mathrm{E}, \mathrm{N} 60^{\circ} \mathrm{E}, \mathrm{N}^{\circ} \mathrm{E}$, and $\mathrm{N}^{\circ} 5^{\circ} \mathrm{E}$. The lower figure is the enlarged area of the lower-left corner of the upper figure. The location of the upper figure is shown in the lower half box of Fig. 1. 
diapir ridges between Tainan and Liuchiuhsu mostly ranges from $\mathrm{N} 30^{\circ} \mathrm{E}$ to $\mathrm{N} 35^{\circ} \mathrm{E}$ (Fig. 1), which is close to the predicted trend of en-echelon folding $\left(\mathrm{N} 35^{\circ} \mathrm{E}\right)$ in the strike-slip deformation model (Fig. 10). This suggests that the en-echelon folding seen both in the field observations of strike-slip environments [1,23] and in experimental studies [22] may be represented here by the diapir ridges shown in Figure 1, and further indicates that the mud diapirs in the study area may have affected by strike-slip deformation component rather than solely by the thrust faulting mechanism, as has been previously suggested by Liu et al. [19].

\section{CHRONOLOGICAL EVOLUTION OF THE ESCAPE STRUCTURE}

The following simplified three-stage chronological evolution is to account for the complex structures in the study area and to explain their neotectonic significance:

In Stage I (Fig. 11), during the Penglai Movement

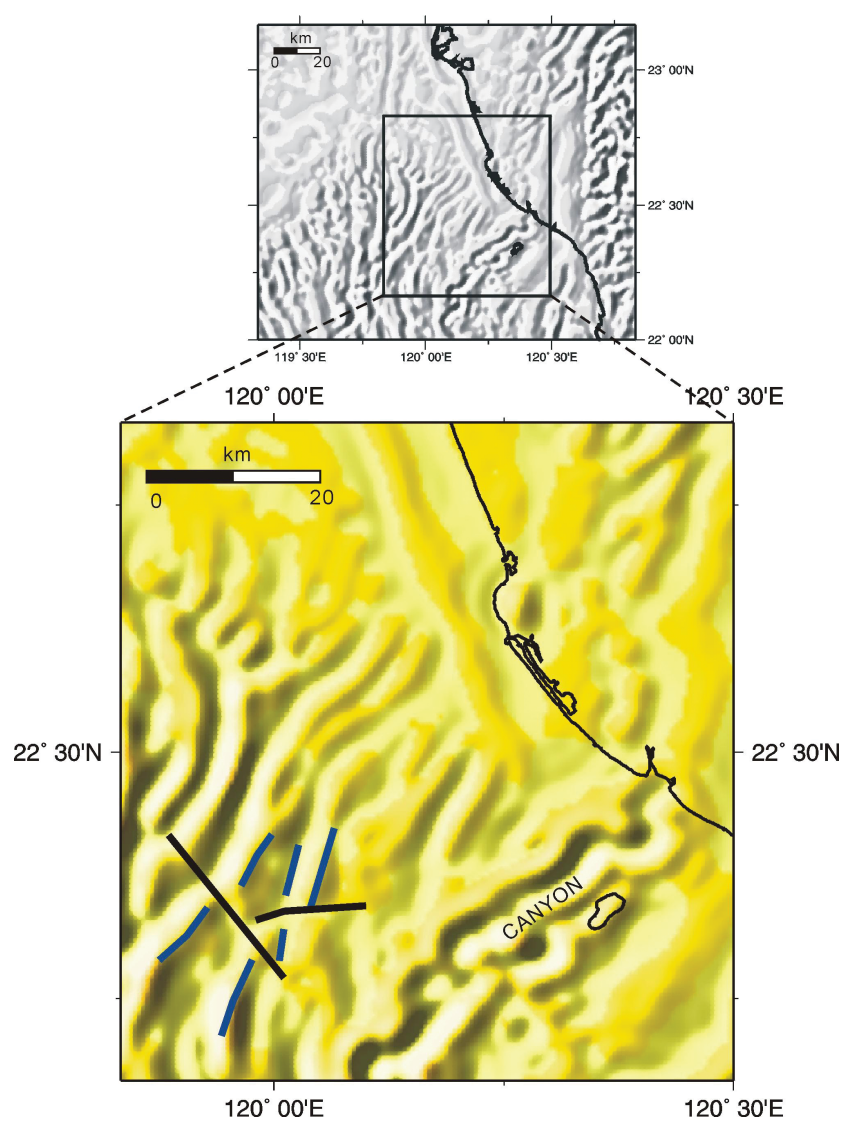

Fig. 6. An inferred fault trending $\mathrm{N} 40^{\circ} \mathrm{W}$. Illumination source is from $\mathrm{S60}^{\circ} \mathrm{E}$. Offset lineaments are indicated with gray lines, and the faults are shown as black lines. The lower figure is the enlarged area of the middle small box of the upper figure. The location of the upper figure is shown in the lower half box of Fig. 1. in the late Pliocene, a series of folds began to form in response to SE-NW compression caused by the collision of the Luzon arc of the Philippine Sea plate with the

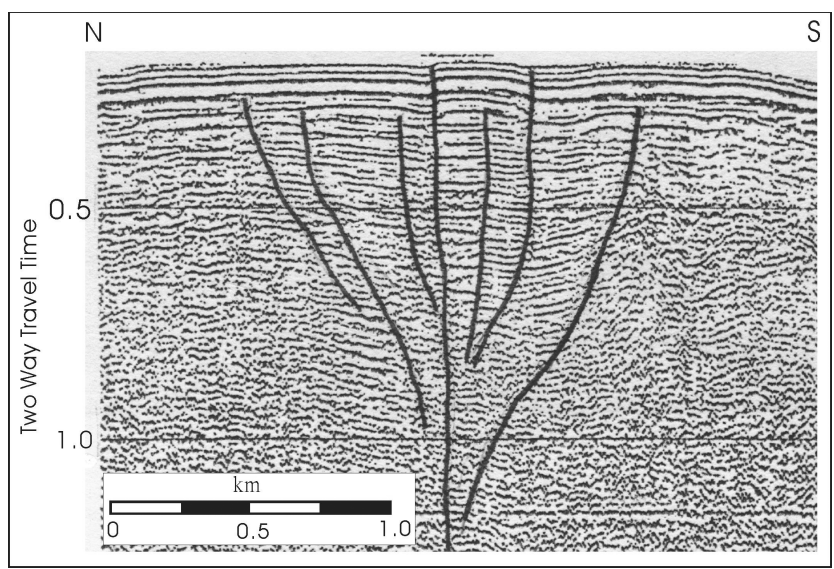

Fig. 7. Transtensional flower structure on seismic line 329-13. Location shown as heavy line in Fig. 1 (Chow et al., 1996).
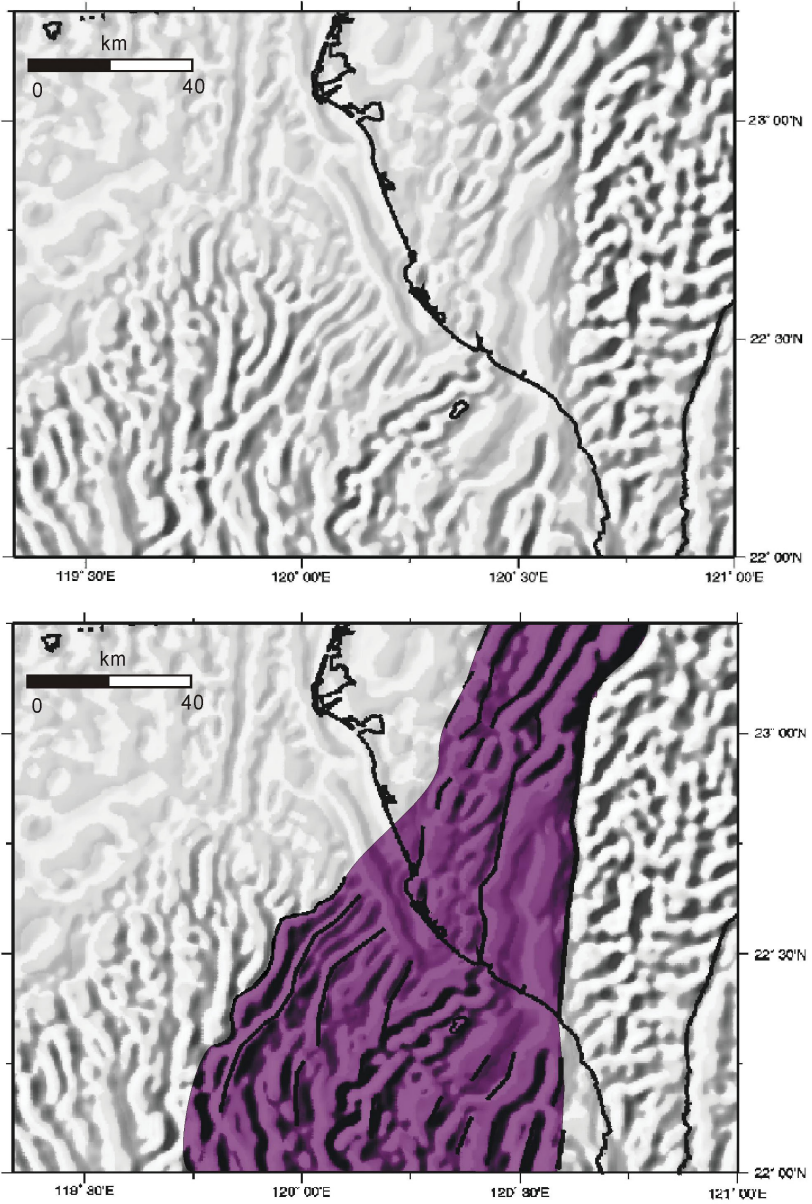

Fig. 8. Fan-shaped pattern (covered by dark color) of lineaments (traced in black), as identified on the topography illuminated from $\mathrm{S} 60^{\circ} \mathrm{E}$. 

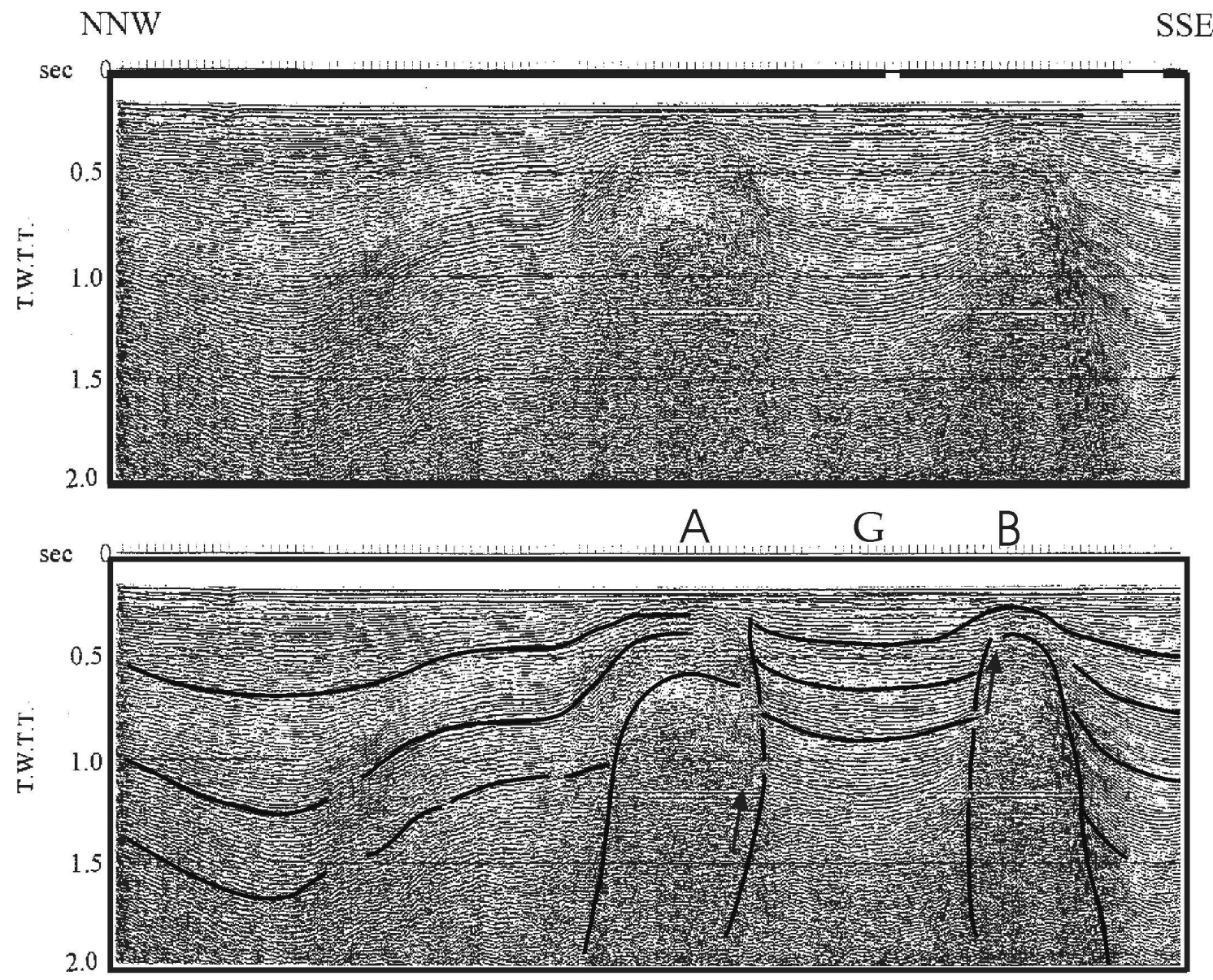

Fig. 9. Seismic profile 329-11 profiles cross the fan-shaped pattern of lineaments, showing the presence of two mud diapirs (A, B) and depression (G). Uninterpreted (upper); interpreted (lower). The location of the seismic section is shown in Fig. 1.

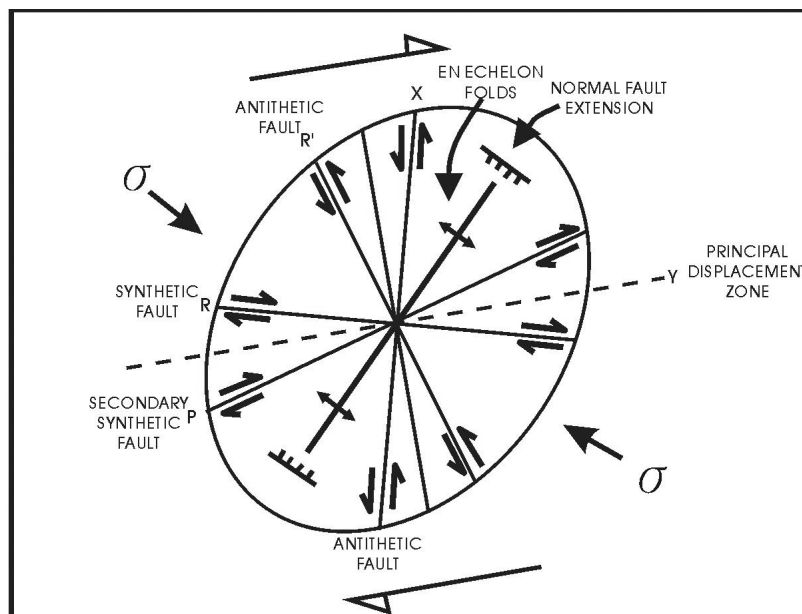

(A)

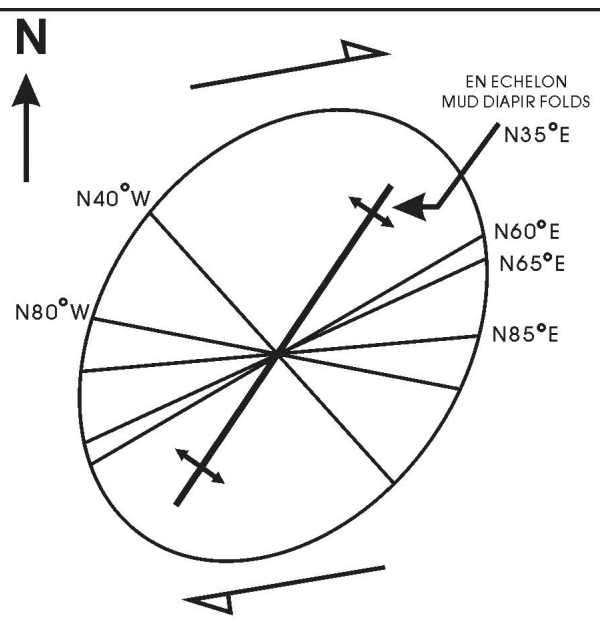

(B)

Fig. 10. (A) Right-lateral strike-slip fault model derived from experimental deformation (modified from Wilcox et al., 1973). (B) Trends of the inferred faults and of the diapir ridges in the study area superimposed on a similar strain ellipse for right-lateral strike slip faulting. The en-echelon diapir ridges in the study area are equivalent to the en-echelon folds in the experimental model, and all the faulting inferred in Figures 5 and 6 is correlated with the structural features predicted by the right-lateral strike-slip deformation model. 


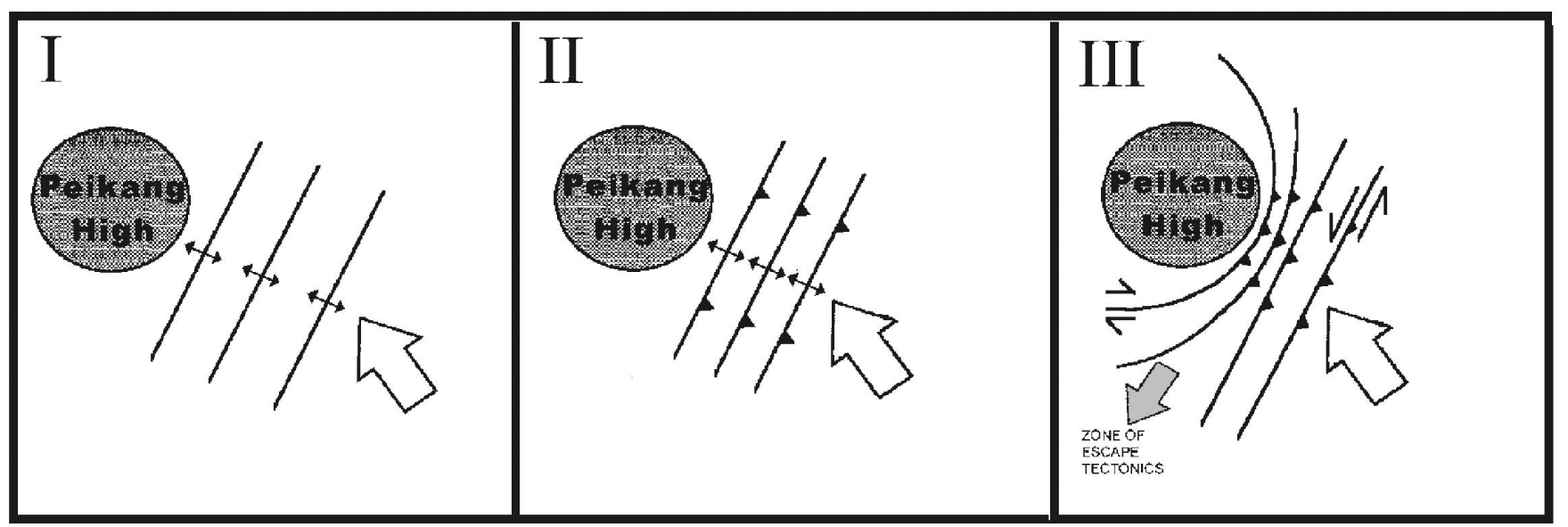

Fig. 11. Proposed evolutionary model for the development of the "zone of escape" structures observed in the study area. I. A series of folds formed as the Philippine Sea plate (white arrow) collided with the Eurasian plate during the Penglai movement in the late Pliocene. II. To the east of the Peikang Basement High indenter, these folds were transformed into thrust faults with a component of left-lateral slip. III. Convergence continues and an area of escape tectonics develops ahead of Peikang High. This area is bounded to the north by right lateral strike-slip faults (these faults are shown in Figure 2) and to the east by thrust faults (Figure 2). The zone of escape tectonics corresponds to the lineament fanning zone in Fig. 7.

Eurasian continental plate [14]. This folding occurred in an area that later became the present-day site of Taiwan. In Stage II (Fig. 11), the collision then reached to the Peikang Basement High, and in the area of headon collision east of the Peikang High, the series of folds was transformed into a series of thrust faults with a component of left-lateral strike slip [3, 7, 17, 20,31]. Finally, in Stage III (Fig. 11), a zone of escape structures formed south of the Peikang High [20]. This area, which corresponds to the lineament fanning zone in Figure 8 , is bounded by thrust faults and right-lateral strike slip faults south of the Peikang High [3, 20]. Southeast of this bounding fault, a series of normal faults and right-lateral strike-slip faults developed within a zone of "escape" tectonics. Consequently, in this escape zone, the original tectonics of the area have been overprinted by strike-slip deformations, such as lineament offsets caused by faulting, flower structures, and mud diapirs.

\section{CONCLUSION}

The fan-shaped distribution pattern of the lineaments off the southwestern coast of Taiwan reveal new evidence in the offshore area. From the offsets of other lineaments, strike-slip faulting is inferred; these faults have azimuths that are consistent with a strain ellipse for a right-lateral shear zone. Flower structures, which are characteristic of strike-slip deformation, have been previously identified in seismic sections in the area. In addition, the en-echelon mud diapir ridges are also compatible with a strike-slip deformation model if it is assumed that they represent the en-echelon folding that is often observed to accompany strike-slip faulting.

\section{ACKNOWLEDGEMENTS}

Thanks are due to Dr. Benoit Deffontaines of Universite Pierre et Marie Curie (France) for careful reading and offering valuable suggestion. This research was supported by the National Science Council of Taiwan Government. We express our appreciation to the officers and crew of the R/V Ocean Researcher I for providing support for seismic survey.

\section{REFERENCES}

1. Bartlett, W.L., Friedman, M., and Logan, J.M., "Experimental Folding and Faulting of Rocks Under Confining Pressure. Part IX. Wrench Faults in Limestone Layers," Tectonophysics, Vol. 79, pp. 255-277 (1981).

2. Biq, C.C., "Kinematic Pattern of Taiwan as An Example of Actual Continent-arc Collision," Report of the Seminar on Seismology US-ROC Cooperative Science Program, pp. 21-26 (1973).

3. Biq, C., "Another Coastal Range on Taiwan," Ti-Chih, Vol. 12, pp. 1-14 (1990).

4. Brown, C., Lu, R., Lee, C.S., and Shouten, H., "Plate Convergence and Accretion in Taiwan-Luzon Region," Am. Assoc. Pet. Geol. Bull., Vol. 62, pp. 1645-1672 (1978).

5. Chang, C.H., "On Mud Diapirs off Southwestern Taiwan," MS Thesis, National Taiwan University, Taipei, Taiwan (1993). 
6. Chang, C.P., Huang, C.Y., Angelier, J., and Lee, T.Q., "From Continental Margin Extension to Collission Orogen: Structural Development and Tectonic Rotation of the Hengchun Peninsula, Southern Taiwan," Tectonophysics, Vol. 361, pp. 61-82 (2003).

7. Chi, W.C. and Dreger, D., "Finite Fault Inversion of the September 25, $1999(\mathrm{Mw}=6.4)$ Taiwan Earthquake: Implications for GPS Displacements of Chi-Chi, Taiwan Earthquake Sequence," Geophys. Res. Lett., Vol. 29, pp. 39-1-39-4 (2002).

8. Chow, J., Lai, T.D., Liu, C.S., and Yu, H.S., "Flower Structures and Strike-slip Deformation off Southwestern Taiwan," TAO, Vol. 4, pp. 523-533 (1996).

9. Chow, J., Lee, J.S., Liu, C.S., Sun, R., and Lundberg, N., "Characteristics of the Bottom Simulating Reflectors Near Mud Diapirs: Offshore Southwestern Taiwan," Geomarine Lett., Vol. 20, pp. 3-9 (2000).

10. Chow J., Angelier, J., Hua, J.J., Lee, J.C., and Sun, R., "Paleoseismic Event and Active Faulting: from Ground Penetrating Radar and High-resolution Seismic Reflection Profiles Across the Chihshang Fault, Eastern Taiwan," Tectonophysics, Vol. 333, pp. 241-259 (2001).

11. Deffontaines, B., Rudant, J., Lee, J.C., Angelier, J., and Carvalho, J., "New Geomorphic Data on the Active Taiwan Orogen: A Multisource Approach," J. Geophys. Res., Vol. 99, pp. 243-266 (1994).

12. Fuh, S. C., Liu, C.S., Lundberg, N., and Reed, D.L., "Strike-Slip Faults Offshore Southern Taiwan, Implications for the Oblique Arc-continent Collision Processes," Tectonics, Vol. 274, pp. 25-39 (1997).

13. Harding, T.P. and Lowell, J.D., "Structure Styles, Their Plate-tectonic Habitats, and Hydrocarbon Traps in Petroleum Provinces. Am. Assoc.," Pet. Geol. Bull., Vol. 63, pp. 1016-1058 (1979).

14. Ho, C.S., "A Synthesis of the Geologic Evolution of Taiwan," Tectonophysics, Vol. 125, pp. 1-16 (1986).

15. Hsieh, S.H., "Subsurface Geology and Gracity Anomalies of the Tainan and Chungchou Structures of the Costal Plain Southwestern Taiwan," Petrol. Geol. Taiwan, Vol. 10, pp. 323-338 (1972).

16. Huang, C.Y., Yuan, P.B., Song, S.R., Lin, C.W., Wang, C., Chen M.T., Shyu, C.T., and Karp, B., "Tectonics of Shoer-live Intra-arc Basin in the Arc-continent Collision Terrain of the Coastal Range, Eastern Taiwan," Tectonics, Vol. 14, pp. 19-38 (1995).

17. Ji, C., Wald, D.J., Helmberger, D.V., Song, T.R.A., and Ma, K.F., "Slip Distribution and Tectonic Implication of the 1999 Chi-Chi, Taiwan, Earthquake," Geophys. Res. Lett., Vol. 28, pp. 4379-4382 (2001).

18. Lallemand, S., Liu, C.S., Angelier, J., and Tsai, Y.B., "Active Subduction and Collision in Southeast Asia," Tectonophysics., Vol. 333, pp. 1-7 (2001).
19. Liu, C.S., Huang, I.L., and Teng, L.S., "Structural Features off Southwestern Taiwan," Marine Geol., Vol. 137, pp. 305-319 (1997).

20. Lu, C.Y., "Neotectonics in the Foreland Thrust Belt of Taiwan," Petrol. Geol. Taiwan, Vol. 29, pp. 1-26 (1994).

21. Oakey, G., “A Structural Fabric Defined by Topographic Lineaments, Correlation with Tertiary Deformation of Ellesmere and Axel Heiberg Islands, Canadian Arctic," J. Geophys. Res., Vol. 99, pp. 20311-20321 (1994).

22. Pan, Y.S., "Interpretation and Seismic Coordination of the Bouguer Gravity Anomalies Obtained in Southwestern Taiwan." Petrol, Geol. Taiwan, Vol. 6, pp. 197-208 (1968).

23. Riedel, W., "Zur Mechanik Geologischer Brucherscheinyngen, Zentrablatt fur Mineralogie," Geologie und Palaeontologie, Vol. 1929(B), pp. 354-368 (1929).

24. Rohr, K.M.M. and Dietrich, J.R., "Strike-slip Tectonics and Development of the Tertiary Queen Charlotte Basin, Offshore Western Canada, Evidence from Seismic Reflection Data," Basin Res., Vol. 4, pp. 1-19 (1992).

25. Sibuet, J.C., Hsu, S.K., Le Pichon, X., Le Formal, P., Reed, D., Moore, G., and Liu, C.S., "East Asia Plate Tectonics Since 15 Ma: Constraints from the Taiwan Region," Tectonophysics, Vol. 344, pp. 103-134 (2002).

26. Siegal, B.S. and Short, N.M., "Significance of Operator Variation and the Angle of Illumination in Lineament Analysis on Synoptic Images," Mod. Geol., Vol. 6, pp. 75-85 (1977).

27. Song, G.S., Ma, C.P., and Yu, H.S., "Fault-Controlled Genesis of the Chilung Sea Valley (Northern Taiwan) Revealed by Topographic Lineaments," Mar. Geol. Vol. 169, pp. 305-325 (2000).

28. Sun, S.C. and Liu, C.S., "Mud Diapir and Submarine Channel Deposits Inoffshore Kaosiung-Hengchun, Southwest Taiwan," Petrol. Geol. Taiwan, Vol. 28, pp. 1-14 (1993).

29. Teng, L., "Geotectonic Evolution of Late Cenozoic Arccontinent Collision in Taiwan," Tectonophysics, Vol. 183, pp. 57-76 (1990).

30. Wilcox, R.E., Harding, T.P., and Seely, D.R., "Basic Wrench Tectonics," Am. Assoc, Pet. Geol. Bull., Vol. 57, pp. 74-96 (1973).

31. Yang, K.M., Chi, W.R., Wu, J.C., and Ting, H.H., "Tectonic Evolution and Mechanisms for Formations of Neogene Extensional Basin in Southwestern Taiwan, Implications for Hydrocarbon Exploration," Annual Meeting of Geological Society of China, Program with Abstracts, pp. 329-395 (1994).

32. Yu, H.S. and Chang, T.F., "The Penghu Submarine Canyon off Southwestern Taiwan: Morphology and Origin," TAO, Vol. 13, pp. 547-562 (2002). 